\title{
The Accounts Receivable \\ Management in \\ Commercial Enterprises \\ of the Installation and \\ Heating Industry
}

Dorota Roszkowska-Hołysz, Ph.D.

The University of Zielona Gróra,

The Faculty of Economics and Management

\section{Introduction}

The building industry, whose part the installation and heating market is, is an industry, which is highly sensitive to economic fluctuations. It is created by building enterprises functioning in the market, performing diverse investment tasks or producing building materials - also the ones carrying out services in the construction field.

In days of economic downturn, only the enterprises wisely managing their assets have a chance to survive in the market. One of the key elements of the current assets are accounts receivables. They should be of constant interest to the management of every enterprise and should be continuously monitored. If they increase, that should be usually interpreted as a negative phenomenon, then the demand of the enterprise for working capital will be bigger. The accounts receivable management is particularly important for every company.

The aim of this article is to demonstrate through a situation analysis of 25 enterprises from entire Poland, belonging to one commercial group that it is in the installation

The Accounts Receivable Management in Commercial Enterprises of the Installation 
and heating market that distributors face payment delays from their customers and actually provide them with a credit. At the same time, they fulfil their obligations towards their suppliers that is forced upon them by the group. It has a negative impact on their liquidity. It forces the enterprises to look for additional funds. The purpose was accomplished through the analysis of the data coming from enterprises - both of statistical data as well as of the overview of the industry analyses of Euler Hermes, which is an insurer of accounts receivable and of the domestic literature on the subject.

\section{The characteristics of the operation market of the enterprises}

It is in the sanitary and heating equipment market that there are producers of sanitary devices and installations as well as of heating installations, which are distributors at the same time. There are wholesalers, which conduct installation of the devices sold, installation companies, which provide simultaneously construction services. It is amongst the enterprises dealing with distribution that there are the following types of companies: producers of the installation articles and devices involved simultaneously trade activity; representatives of foreign producers, importers, nationwide wholesale companies, local wholesale companies often being a member of purchase groups. The vast variety appearing here results from the multichannel structure of the distribution, from vertical and horizontal integration of companies and from taking different decisions on the offered assortment by the companies.

It is very difficult for Polish enterprises tocompete with big foreign hypermarkets and large dealers in this market. The market consolidation is already not a new phenomenon and it is still in progress. Companies create purchase groups. They make joint purchases by manufacturers through the companies established by them. Since such purchases are quantitatively accumulated, the purchasing entity (the purchase group) obtains favourable price conditions that are better than in case of purchases made by individual entities. As a result the final price for the consumer is lower or the surplus stays by such enterprise.

The enterprises, whose situation is subject to the analysis in this article, are local distributors and wholesale companies. Their existence is mostly dependent on having their own group of regular customers, i.e. installation companies. They belong to a nationwide purchase group in Poland. They reflect the situation of the local distribution level. The installation companies make purchases related to the specific orders of final consumers - very often on their behalf. The installation articles are resold along with the installation service later. 
The installation companies conduct also service activities very often, which are associated with the installation design or they conduct also wholesale activity, which is not related to the services performed. These can be executive, design-executive, trade-executive and design-trade-executive companies.

The competition in the market is very intense. In the circumstances described above, it is understandable to take care of regular customers, which are mostly executive companies. The possession of a loyal group of customers is a condition for functioning of a wholesale company. The enterprises usually use loyalty programs; they award the best customers with the points, which can be exchanged for various prizes. They divide them into discount groups and apply different conditions of trade credits. A purchase group supports marketing activity of its members.

\section{The essence of a trade credit}

The literature in the field of accounting and finances uses the division of assets into fixed and current assets. A universal dictionary of the Polish language (2003, p. 532) defines assets as all goods being a property of a given person or a given institution including ownership of movable and immoveable assets. These are current assets that are the subject of the interest of this article. The elements of current assets can be tangible (inventories) and financial.

Keeping tangible assets requires covering the costs of the capital involved in them as in case of financial components. The possession of stocks (inventories) is associated with a higher risk, since before they are cashed, they go through a number of transitional phases. (Bien 2005, p. 211) The components of current assets include the components of the company assets, which in the economic process can change their form into financial one; inventories, receivables, cash and other assets. The basis for the calculation of the current assets of the company involves the balance sheet positions, which are combined into groups with similar characteristics.

Accounts receivables of a company result from sale, if a payment is made by a customer at a later date than the purchase date and the date of delivering a bill to the customer (Bien 2005, p. 221). It is providing trade credit that is a key element of operations of any commercial enterprise. It helps to maintain a competitive position. It affects sales volume, supports keeping customers but also lowers financial liquidity and increases the risk of the given business activity. It is in times, when there is a stagnation in the market that payment delays occur, which result in additional execution costs. The maintenance

The Accounts Receivable Management in Commercial Enterprises of the Installation and Heating Industry 
of an adequate liquidity level is a prerequisite for survival in the market. The importance of this issue requires deliberate efforts of the company. It is in the market being in focus of this article that providing the trade credit is one of main forms of account settlements between contracting parties.

A trade credit is being granted by a seller of goods, materials or of services to a buyer and has a form of a deferred payment period in relation to the date of the sale (Bień 2005, p. 221). The meanings of the notions of a merchant credit and trade credit are the same (Szczepański, Szyszko 2007, p. 429). Granting a trade credit can be manipulative. The sale is treated as cash; the due date is most often set for a few days after issuing an invoice (Rytko 2009, p. 15). The recipient has time to accept goods, to check their compliance with his order and the invoice, and to make a transfer in a bank. A trade credit may also have the nature of a merchant credit. A longer deferred payment period is set and the contracting party is being provided with a credit. The period of settling accounts is usually from 7 up to 20 days and it is dependent on the customs adopted in the given industry and on the type of offered goods.

Granting a trade credit is associated with an operating cycle of a working capital in an enterprise. The current assets involved in the constantly recurring operations include both financial assets as well as tangible assets. The operating cycle of working capital, which shows the way of the working capital management, starts with the purchase of goods and materials and it ends, when the cash from the sales of goods and finished products is received. It consists of the period of keeping and trading the inventories and of the receivables collection period. When an enterprise purchases goods or materials with a deferred payment period, an accounts settlement period occurs. It reduces the gross working capital cycle and the difference is a cash trading period (a cash conversion cycle), that is the time, for which additional funds are needed to run a business (Rutkowski 2007, p. 390, Sierpińska, Jachna 2004, s.153). The receivables collection period in the analysed enterprises is extending together with increase in the collection period and it is not a positive phenomenon. The table 1 shows the operating cycle and the cash conversion cycle.

A large part of assets of enterprises is in receivables. These are the assets, over which the companies do not exercise full control. The appearance of payment backlogs may lead to a loss of liquidity and even to bankruptcies. An important element of the accounts receivable management in an enterprise is the control and collection of receivables. The aim is to eliminate bad debts and it is executed through the effective debt collection. In the enterprises belonging to the group the level of receivables is monitored and the employees are required to act in order 
Table 1. Gross and net working capital cycle in the examined enterprises

\begin{tabular}{c|c|c|c|c|c}
\hline Years & $\begin{array}{c}\text { Liabilities } \\
\text { payment period }\end{array}$ & $\begin{array}{c}\text { The period } \\
\text { of keeping } \\
\text { inventories }\end{array}$ & $\begin{array}{c}\text { Receivables } \\
\text { collection } \\
\text { period }\end{array}$ & $\begin{array}{c}\text { Cash } \\
\text { conversion } \\
\text { cycle }\end{array}$ & $\begin{array}{c}\text { Operating } \\
\text { cycle }\end{array}$ \\
\hline 2008 & 80 & 86 & 75 & 81 & 161 \\
\hline 2009 & 85 & 94 & 91 & 100 & 185 \\
\hline 2010 & 92 & 105 & 96 & 109 & 201 \\
\hline 2011 & 83 & 98 & 92 & 107 & 190 \\
\hline 2012 & 83 & 109 & 102 & 128 & 211 \\
\hline
\end{tabular}

Source: own calculations based on financial statements of the purchase group

to encourage contractors to settle accounts. It should be noted that an important tool for controlling and monitoring receivables is grouping them according to the time and their emergence. It facilitates the control. The most difficult cases, in which the probability of the cash collection by mutual agreement is very low, shall be referred to the debt collection proceedings. The purchase group has a contract with an external debt collection company, which supports the companies on favourable terms. The economies of scale are also used on this field. The overdue receivables account for about $37 \%$ of total receivables. The payment period in the analysed time was from 83 up to 85 days. Only in 2010, this indicator increased to 92 days. The inventory ratio was gradually lengthened in the analysed. The enterprises paid their liabilities faster than they received payments from their debtors. The gross cycle was 211 days in 2012 and it was the longest in the analysed time period. This increase was caused by extended inventory ratios and receivables. The cash trading period grew from 81 up to 128 days and this phenomenon cannot be assessed positively. It is in order to continue business activity in such a situation that extra money is needed. The aim is to shorten this period as much as possible. The cash trading period can be shorten by accelerating the inventory turnover and receivables collection as well as by delaying payments of liabilities. However, it is in the days of a bad situation on the market and in the situation of cooperating in a group, which is pushing for timely payment of obligations that it is difficult to implement such a policy.

The decision to grant a trade credit should be considered in a broader context of its impact on various areas of the company's activity. The financial methods 
for assessing the credit policy of the given company cannot be the only criterion for the choice of the way of crediting customers. They can be a good and complementary tool for facilitating evaluation and optimization of the decision on providing trade credit (Rutkowski, p. 445). However, the contractors being in arrears with payments, mostly have a long history of the cooperation with the distributor. It was difficult to anticipate that they would be in such a difficult situation, which would be transferred by them to their suppliers.

The trade credit is a part of current assets; it is posted as receivables, which are included in assets of the balance sheet. Apart from receivables, the current assets include cash, funds on bank accounts, financial assets in the form of investments in securities and stocks. The inventories turn into receivables, when they are sold with the use of the trade credit or cash. The current assets being subject to a constant transformation provide the operational continuity of the enterprise.

\section{The evolution of receivables for supplies and services by suppliers of heating} and sanitary devices and installations on the background of receivables for supplies and services by construction companies in the years 2008-2012

The analysis of the current assets of the companies of the construction industry was carried out on the basis of the table 2. It shows a progressive increase in the current assets of Polish enterprises as well as in trade receivables. The share of the trade receivables for supplies and services, generally speaking, amounted $42.18 \%$ in 2009; it felt to $31.37 \%$ in 2009 and increased to $35.59 \%$ in 2011. 2012 brought a decline in all components of current assets.

Table 2. Current assets of Polish construction enterprises in the years 2005-2012 (millions PLN)

\begin{tabular}{|c|c|c|c|c|c|c|c|}
\hline \multirow[b]{2}{*}{ Years } & \multirow[b]{2}{*}{ Total } & \multirow[b]{2}{*}{$\begin{array}{l}\text { Invento- } \\
\text { ries }\end{array}$} & \multicolumn{2}{|c|}{ Receivables } & \multirow{2}{*}{$\begin{array}{l}\text { Short-term } \\
\text { invest- } \\
\text { ments }\end{array}$} & \multirow[b]{2}{*}{$\begin{array}{c}\text { Prepay- } \\
\text { ments }\end{array}$} & \multirow{2}{*}{$\begin{array}{c}\text { The share } \\
\text { of receivables } \\
\text { for supplies and } \\
\text { services } \\
\text { in total current } \\
\text { assets }\end{array}$} \\
\hline & & & Total & $\begin{array}{l}\text { For } \\
\text { supplies } \\
\text { and } \\
\text { services }\end{array}$ & & & \\
\hline 2008 & 42729 & 7585 & 20349 & 18023 & 11643 & 3152 & $42,18 \%$ \\
\hline 2009 & 55953 & 14379 & 20276 & 17552 & 18147 & 3151 & $31,37 \%$ \\
\hline
\end{tabular}




\begin{tabular}{l|l|l|l|l|l|l|l}
2010 & 55383 & 12402 & 20995 & 18187 & 18138 & 3848 & $32,84 \%$ \\
\hline 2011 & 61711 & 13721 & 25394 & 21966 & 15986 & 6610 & $35,59 \%$ \\
\hline 2012 & 58347 & 12967 & 22745 & 19596 & 15552 & 7083 & $33,58 \%$ \\
\hline
\end{tabular}

Source: own study on the base: „The small statistical GUS yearbook", 2008, p. 392, 2010, p. 404,2011 p. 406,2009 p. 394,2007 p. 396,2006, p. 387,2012 , p. 409,2013 , p. 415

The last years were dominated by the effects of the financial crisis. These are not only construction companies that have problems with recovering their own funds as well as with raising new funds on the market. Banks have reduced both financing investments as well as current assets of companies. In 2012, 273 construction companies went bankrupted; it was $87 \%$ more than in 2011 and more than seven times more than five years ago (in 2007 there were only 37 bankruptcies in the construction industry). The average payment collection time for the goods sold by construction wholesale companies is 85 days at present (Euler Hermes 2012).

The table 3 present the development of current assets of the examined enterprises in the analogous time period. It should be noted that these are accumulated data.

Table 3: Current assets of the examined enterprises in the years 2008-2012 (in PLN)

\begin{tabular}{|c|c|c|c|c|c|c|c|}
\hline \multirow[b]{2}{*}{ Years } & \multirow[b]{2}{*}{ Total } & \multirow[b]{2}{*}{$\begin{array}{l}\text { Invento- } \\
\text { ries }\end{array}$} & \multicolumn{2}{|c|}{ Receivables } & \multirow{2}{*}{$\begin{array}{l}\text { Short- } \\
\text { term } \\
\text { invest- } \\
\text { ments }\end{array}$} & \multirow[b]{2}{*}{$\begin{array}{l}\text { Prepay- } \\
\text { ments }\end{array}$} & \multirow{2}{*}{$\begin{array}{l}\text { The share of } \\
\text { receivables } \\
\text { for supplies } \\
\text { and services } \\
\text { in total cur- } \\
\text { rent assets }\end{array}$} \\
\hline & & & Total & $\begin{array}{l}\text { For sup- } \\
\text { plies and } \\
\text { services }\end{array}$ & & & \\
\hline 2008 & 264998327 & 120719604 & 132275491 & 124403655 & 9236511 & 2766721 & $47 \%$ \\
\hline 2009 & 276850356 & 118722461 & 146371173 & 132866230 & 9256376 & 2500346 & $48 \%$ \\
\hline 2010 & 321051983 & 139657147 & 161716484 & 152247349 & 16282748 & 3395604 & $47 \%$ \\
\hline 2011 & 353124832 & 152844472 & 178448590 & 167675288 & 18927123 & 2904647 & $47 \%$ \\
\hline 2012 & 348223742 & 149867221 & 173015947 & 165471151 & 23153688 & 2186886 & $48 \%$ \\
\hline
\end{tabular}

Source: own study based on financial statements of the group for the years 2008-2012 
It was in the recent years that the suppliers successively increased their current assets. It resulted from the increase in inventories. The nominal value of the short-term receivables also tends to increase at the pace of about $10 \%$ against the previous year. The share of trade receivables for supplies and services in the total current assets fluctuates around $48 \%$ in the analysed period and is higher than the share of inventories in the current assets (on average by $43 \%$ ). It proves widespread use of the trade credit by enterprises. It also exceeds the analogous rate calculated by the GUS for the construction companies in the analysed period.

An indicator for the nature and real credit relations amongst contracting parties is the credit position indicator. It relates receivables from recipients and obligations towards suppliers. The value of the indicator above 1 shows the better position of a lender and the value below 1 shows the better position of a borrower. (Zimon 2012, p. 776). The table 4 below presents values of the indicator calculated in individual years.

\section{Table 4. The value of the credit position indicator} for the examined enterprises

\begin{tabular}{|c|c|}
\hline Years & WPK \\
\hline 2008 & 1,2 \\
\hline 2009 & 1,4 \\
\hline 2010 & 1,3 \\
\hline 2011 & 1,3 \\
\hline 2012 & 1,5 \\
\hline
\end{tabular}

The credit position indicator indicates that it was in all analysed years that the companies were a source of credit for their customers. The distributors participate in financing the business activity of their customers. Given the desire to continue the good cooperation in future, they do not charge interest on overdue debts. It is a cheap source of financing for contractors. 


\section{Summary}

The functioning on the market of distributors of sanitary and heating installations is a capital intensive business. It is mainly due to high prices of the offered goods. It is maintaining inventories that requires appropriate buildings and sometimes adequate temperature that is associated with insurance and other costs.

The customary merchant credit for customers is also significant. The specificity of the market forces applying the trade credit upon the companies, as an instrument to boost the good cooperation with contractors. Companies are trying to attract customers favorable terms of purchase. Through extended loan periods try to influence the current and future sales volume, these decisions have both; financial and marketing dimension (Rutkowski 2007, s.429).The receivables in the balance sheets of the wholesale companies are generally twice as much as the value of inventories. A part of receivables is hard to recover. It is caused by payment backlogs in the construction industry, which is experiencing a crisis at the moment.

While creating a policy for the accounts receivable management, the criteria for evaluating the customers' reliability should be taken into account as well as payment conditions applicable to the sale and the way for collection of debts. Sales professional must be alert to any signs of emerging financial difficulties of the recipients. The most convenient payment terms should receive trusted customers with the longest history of purchasing. Rewarding for sale, which is a tool for motivating employees to better work should be carried out at the time of the actual impact of the money, not at the end of the month, as it is practiced. This will be an additional tool to motivate retailers to thoughtful action. Procedures for redress must be taken to plan.

The membership in a purchase group changes the structure of the current assets of enterprises. On the one hand, there is a certain level of orders, which have to be placed that forces sometimes keeping a higher than optimal level of inventories, however, on the other hand, the favourable acquisition conditions have their reflection in prices of the goods. The group is supporting their members in marketing activity; it uses economies of scale at acquisition of services of mobile communications. It tries to support the companies in enforcement proceedings. It also prevents the appearance of overdue liabilities by not allowing companies to finance from such sources themselves. 


\section{Summary}

The Accounts Receivable Management in Commercial Enterprises of the Installation and Heating Industry

The article presents the issues of managing current assets in trade enterprises on the market of sanitary and heating devices and installations. It is a capital intensive activity and the current assets being receivables are characterized by a high risk level. Distributors finance executing companies, which commonly use trade credit.

Keywords: current assets, merchant credit, trade credit, market of sanitary and heating installations.

\section{Streszczenie}

Gospodarowanie należnościami w przedsiębiorstwach handlowych branży instalacyjno- grzewczej

Artykuł przedstawia problematykę gospodarowania majątkiem obrotowym $\mathrm{w}$ przedsiębiorstwach handlowych na rynku urządzeń i instalacji sanitarno- grzewczych. Jest to działalność kapitałochłonna, aktywa obrotowe będące należnościami charakteryzują się wyższym poziomem ryzyka. Dystrybutorzy finansują firmy wykonawcze, które powszechnie korzystają z kredytu kupieckiego.

Stowa

kluczowe: majątek obrotowy, kredyt kupiecki, rynek instalacji sanitarno-grzewczych.

\section{References}

1. Bień W. (2005), Zarządzanie finansami przedsiębiorstwa, Difin, Warszawa.

2. Czekaj J., Dresler Z., Zarzadzanie finansami przedsiębiorstw. Podstawy teorii, PWN, Warszawa.

3. Euler Hermes, Informacja prasowa $z$ dnia 8.01.2013, www.eulerhermes/pl/ dokumenty/130108_eh_upadlosci_2012.pdf.

4. Szczepański J., Szyszko L. (red.) (2007), Finanse przedsiębiorstwa, PWE, Warszawa.

5. Rytko P. (2009), Zarządzanie kredytem handlowym w małych i średnich przedsiębiorstwach, Difin, Warszawa.

6. Mały Rocznik Statystyczny 2006, 2007, 2008, 2009, 2010, 2011, 2012, 2013 ze strony http://www.stat.gov.pl/gus/5840_737_PLK_HTML. htm?action=show_archive, 5.09.2013. 
7. Rutkowski A. (2007), Zarządzanie finansami, PWE, Warszawa.

8. Sierpińska M., Jachna T. (2004), Ocena przedsiębiorstwa wedtug standardów światowych, PWN, Warszawa.

9. Uniwersalny słownik języka polskiego PWN, Wersja 3.0, (2008), Warszawa.

10. Zimon G. (2013), Kontrola i zarządzanie należnościami w przedsiębiorstwach tworzacych grupy zakupowe, Zeszyty Naukowe Uniwersytetu Szczecińskiego nr 766, Finanse, rynki finansowe, ubezpieczenia nr 62, Szczecin. 